\title{
Empowerment in pregnancy: study on the adaptation of the Em- powerment Scale for Pregnant Women to the Portuguese context
}

\author{
Empowerment na gravidez: estudo de adaptação da Empowerment Scale for Pregnant \\ Women para o contexto português \\ Empoderamiento en el embarazo: un estudio de adaptación de la Empowerment Scale for \\ Pregnant Women para el contexto português
}

Clara Maria Cardoso da Silva Aires*; Isabel Maria Fonseca Ferreira**; Alzira Teresa Vieira Martins Ferreira dos

Santos***; Maria Rui Miranda Grilo Correia de Sousa****

\begin{abstract}
Background: Nursing prenatal care should be based on a dynamic process of listening, trust, respect and negotiation with couples. Objectives: The purpose of this methodological study was the cultural adaptation of the Empowerment Scale for Pregnant Women (ESPW) to the Portuguese population and its psychometric evaluation.

Methodology: The instrument was applied to a non-probability accidental sample of 166 pregnant women, between 12 to 41 weeks of gestation and aged 18 or more years. In order to assess the psychometric properties of the scale, we used construct and criterion validity and analyzed its internal consistency.

Results: The principal components analysis with 5 factors (Self-efficacy, Future Image, Self-Esteem, Support and Assurance from Others, and Joy of an Addition to the Family), which explain 50.76\% of the total variance. The scale revealed a overall internal consistency of 88 .

Conclusion: The Portuguese version of the ESPW (EEG, Escala de Empowerment da Grávida) proved to be a reliable and useful instrument to measure the empowerment of Portuguese pregnant women.
\end{abstract}

Keywords: power; prenatal care; pregnant

\section{Resumo}

Enquadramento: Os cuidados de enfermagem no contexto da gravidez deverão basear-se num processo de atuação dinâmico, de escuta, confiança, respeito e negociação com os casais. Objetivos: O presente estudo metodológico teve como objetivo a adaptação cultural para o contexto português da Empowerment Scale for Pregnant Women e respetiva avaliação psicométrica.

Metodologia: $\mathrm{O}$ instrumento foi aplicado a uma amostra não probabilística acidental de 166 grávidas, com idade gestacional entre 12 e 41 semanas e com idade igual ou superior a 18 anos. Para avaliar as propriedades métricas da escala recorreu-se à validação de construto e de critério e à análise de consistência interna. Resultados: A análise dos componentes principais fixada a 5 fatores confirma as dimensões propostas pelas autoras (Autoeficácia, Previsão do Futuro, Autoestima, Apoio e Segurança de Outros e Alegria pela Inclusão de um Novo Membro na Família), explicando $50,76 \%$ da variância total. A escala revelou uma consistência interna global de 0,88 .

Conclusão: A escala de empowerment da Grávida mostrou ser um instrumento fiável, válido e útil para medir o empowerment das grávidas portuguesas.

Palavras-chave: poder; cuidado pré-natal; grávida

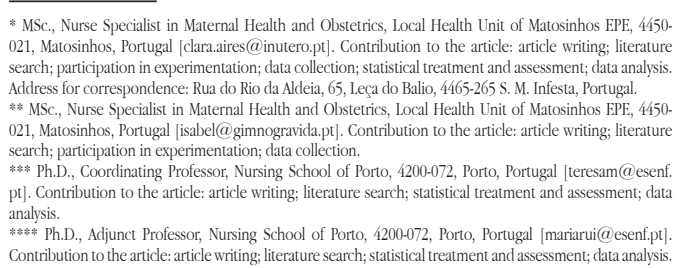

\section{Resumen}

Marco contextual: Los cuidados de enfermería durante el embarazo deben basarse en un proceso de actuación dinámico, de escucha, confianza, respeto y negociación con la pareja.

Objetivos: Este estudio metodológico tiene como objetivo la adaptación cultural a la realidad portuguesa de la Empowerment Scale for Pregnant Women de Kameda y Shimada (2008), así como su evaluación psicométrica.

Metodología: El instrumento se aplicó a una muestra accidental no probabilística de 166 embarazadas con una edad de gestación de 12 a 41 semanas y con una edad igual o superior a 18 años. Para evaluar las propiedades métricas de la escala se recurrió a la validación de constructo y de criterio y al análisis de la consistencia interna.

Resultados: El análisis de los componentes principales sujeto a 5 factores confirma las dimensiones propuestas por las autoras (Autoeficacia, Previsión de Futuro, Autoestima, Apoyo y Seguridad de Otros y Alegría por la Inclusión de un Nuevo Miembro en la Familia), lo que explica el 50,76\% de la varianza total. La escala reveló una consistencia interna global de 0,88. Conclusión: La Empowerment Scale for Pregnant Women se mostró como un instrumento fiable, válido y útil para medir el empoderamiento de las embarazadas portuguesas.

Palabras clave: poder, atención prenatal; embarazada

Received for publication: 15.04 .16 Accepted for publication: 26.07 .16 


\section{Introduction}

According to Gibson (1991), empowerment is a social process of realizing the need to promote and improve the citizens' ability to satisfy their own needs, solve their own problems, and acquire the resources necessary to take control of their lives.

The World Health Organization (OMS, 2001) defines empowerment as a continuous process through which individuals and/or communities acquire and gain confidence, self-esteem, understanding and power needed to meet their needs, aware that it is essential to gain control over their lives, specifically their health.

From this perspective, nursing interventions must incorporate strategies to raise awareness and facilitate the access to personal and social resources, empowering people to have a direct influence in their own health (Conselho Internacional de Enfermeiros, 2002).

This study aims to culturally adapt and assess the psychometric properties of the Empowerment Scale for Pregnant Women for the Portuguese population.

Applying this scale in clinical practice will allow identifying pregnant women's needs, understanding how they experience pregnancy and the transition to parenthood, and contributing to focus nursing care on the clients and their needs.

The research on empowerment in nursing care during pregnancy may contribute to increase knowledge about nurses' performance and associated gains.

\section{Background}

Pregnancy and the transition to parenthood are memorable and extremely important stages in women's lives. Hence, nursing interventions during pregnancy should be based on a dynamic process that facilitates listening and negotiation with the pregnant woman/couple and develops a relationship of trust and mutual respect.

According to Kameda and Shimada (2008), the empowerment of pregnant women is defined as a sense of self-fulfillment and increased independence, gained through interaction with the environment and other individuals, leading to an increase in the psychological energy to achieve of the experience of pregnancy and childbirth that they desire.
Given the dynamic and multidimensional nature of the concept of empowerment, its operationalization requires specific situational characteristics of the population and the context under analysis.

Literature on empowerment in the specific context of pregnancy is scarce. We also found no instrument in Portuguese for its assessment in this specific stage of transition and the identification of pregnant women's actual care needs.

Kameda and Shimada (2008) built the Empowerment Scale for Pregnant Women (ESPW) with the purpose of assessing prenatal education and the level of empowerment of pregnant women, from a multidimensional perspective focused on selfresponsibility and autonomy for the self-fulfillment of their own health. The scale is composed of 27 items divided into five dimensions: Self-efficacy (items 1, 4, $13,15,21,23$ ); Future Image (items $2^{*}, 6^{*}, 8,12,17,25$ ); Self-esteem (items 5, 7, 9*, 16, 19*, 22, 27); Support and Assurance from Others $(3,18,24,26)$ and Joy (10, 11, 14, 20 items). Items marked with an asterisk are reversed. Each item is measured on a 4-point Likerttype scale: 1 I strongly disagree; 2 I disagree; 3 I agree and 4 I strongly agree, assuming that the higher the score, the greater the level of empowerment.

\section{Research Question}

This study aims to answer the following question: Is the Escala de Empowerment da Grávida valid and reliable for the Portuguese context?

\section{Methodology}

For the process of adaptation of the ESPW, we followed the guidelines for the cultural adaptation of measurement instruments proposed by Beaton, Bombardier, Guillemin, and Ferraz (2000).

Based on the original version of the ESPW, we requested a graduate in Applied Languages (specialization in Translation) to translate the scale. We also asked a group of experts (three nurses specialized in Maternal and Obstetric Health) to independently translate it into Portuguese. After this analysis, we obtained a consensus version of the scale translated into Portuguese, which was then back-translated into English by another professional 
graduated in Applied Languages without knowledge of the subject area explored in the instrument or of the original version. The group of experts analyzed once again the consensus version and the backtranslation. We contacted one of the authors of the study on the original version to request clarification of the semantic meaning of some questions. This author approved the back-translation.

The Portuguese version of the instrument - Escala de Empowerment da Grávida (EEG) - was applied to 30 pregnant women as a pre-test.

To analyze the validity of the EEG, we designed a sociodemographic and clinical questionnaire on the pregnant women's age, level of education, gestational age, presence of fertility treatments, desire for pregnancy, existence of children and, if so, the type of delivery and perception of previous experience, presence of complications in the current pregnancy, and frequency of childbirth preparation classes.

We also used the adapted version of the empowerment scale of Rogers et al. (1997), which was adapted and validated for the Portuguese population by Almeida and Pais-Ribeiro (2011). This scale consists of 28 items divided into five dimensions: Self-esteem and Self-efficacy, Power/Powerlessness, Community Activism, Optimism and Control over the Future, and Righteous Anger. Each item is measured on a 4-point Likert-type scale from 1 Strongly disagree (lower empowerment) to 4 Strongly agree (higher empowerment), with the exception of items of the Power/Powerlessness dimension and item 4 of the Righteous Anger dimension, which are reversed. A higher score corresponds to a higher level of empowerment, with the final score ranging from 28 to 112. This scale was chosen because, similarly to the scale being validated in this study, it assesses empowerment as a selfperceived construct with multiple dimensions: Critical Awareness (of the resources available in the context), Control (over one's own life) and Participation in Community Organizations (Zimmerman \& Perkins, 1995). Thus, this instrument assesses empowerment at the individual (psychological), organizational and community levels in a general context.

We also used a single-item scale on perceived health status, whose score varied between 1 very poor and 7 very good. This type of scale allows optimizing the data collection process. According to Ribeiro (2005), a very high correlation has been observed between the overall perception of the health status and the SF-36 Health
Status Questionnaire, which could allow replacing a large number of questions with a single item.

The non-probability accidental sample consisted of 166 pregnant women, who were accompanied during their childbirth and parenthood preparation classes in institutions with maternal health and obstetric services. The inclusion criteria were: pregnant women at 12 to 41 weeks of gestation, aged 18 or more years, living in the area of influence of the maternal health and obstetric institutions, and who agreed to participate in the study.

Participants' mean age was 30.15 years, their mean level of education was 14.32 years, and most of them were primigravidae and in the $3^{\text {rd }}$ trimester of gestation. We also observed that most of them (96.99\%) had a desired pregnancy and only four reported having done fertility treatments.

The Ethics Committee and the Board of Directors of the institutions gave their permission to conduct the study. Pregnant women were first contacted to give their consent after clarification of the study objectives and assurance of the voluntary nature of participation and data anonymity. The questionnaires were only applied to the pregnant women who, after clarification of the study scope, agreed to voluntarily participate in the study. They were informed that they could withdraw at any time, without any kind of prejudice.

Before questionnaire completion, some additional clarifications were made. The questionnaire was completed face-to-face or later on at home, and in those cases the questionnaire was delivered in the following contact.

Participants completed the questionnaire in approximately 10 minutes. All questionnaires were completed by the pregnant women without any intervention by the researcher.

Data were collected between March and May 2012. Data were statistically analyzed using descriptive and inferential statistics, obtained through the IBM-SPSS software (Statistical Package for the Social Sciences), version 20 for Windows.

\section{Results}

The participants' mean age was 30.15 years $(S D=$ 4.54), ranging from 18 to 40 years. The mean level of education in the sample was 14.32 years. The 
gestational age varied between 12 and 40 weeks, with a mean of 30.72 weeks. Most pregnant women (161; 96.99\%) had a desired pregnancy. Only four (2.41\%) women had fertility treatments. Most of them (113; 68.07\%) had never been pregnant and 35 (21.08\%) were already mothers. Of these, 17 (10.24\%) reported having had a vaginal delivery, seven (4.22\%) had a vacuum or forceps delivery, and 11 (6.63\%) had a cesarean section. With regard to the perception of the previous labor experience, only two women reported having had a less positive experience.

Face validity of the scale was analyzed in 30 participants. The completion time was, on average, 10 minutes. Pregnant women were asked regarding the existence of items difficult to understand or unclear, and the overall level of difficulty. They all found that the questions were easy to understand and answer. Through descriptive analysis, the EEG showed a high level of empowerment among participants (Table 1). We also found that some questions have a ceiling effect, and that there may be asymmetry and flattening phenomena. The items "I feel affection for my unborn baby" and "I would like to enjoy my pregnancy" were mostly rated as I strongly agree.

Table 1

Minimum (Min) and maximum (Max) values, mean (M) and standard deviation (SD), asymmetry (AS) and flattening (FLA) values per item of the Escala de Empowerment da Grávida

\begin{tabular}{|c|c|c|c|c|c|}
\hline Itens & $\begin{array}{l}\text { Min- } \\
\text { Max }\end{array}$ & M & SD & AS & FLA \\
\hline 1. I can obtain information I need from medical professionals. & $1-4$ & 3.55 & 0.55 & -0.87 & 1.07 \\
\hline 2. I cannot imagine myself raising children. & $1-4$ & 3.66 & 0.60 & -1.94 & 4.19 \\
\hline 3. I can ask for help when I need to. & $2-4$ & 3.49 & 0.51 & -0.11 & -1.67 \\
\hline 4. I can probably take care of what I need to do during the pregnancy. & $1-4$ & 3.40 & 0.57 & -0.53 & 0.46 \\
\hline 5. Even when I feel anxiety, I can shift certain emotional gears & $1-4$ & 3.01 & 0.55 & -0.45 & 2.17 \\
\hline 6. I cannot imagine an increase of my family. & $1-4$ & 3.61 & 0.64 & -1.85 & 3.86 \\
\hline 7. I probably can deliver like other people. & $1-4$ & 3.51 & 0.57 & -0.85 & 0.87 \\
\hline 8. I have my ideal image of childbirth. & $1-4$ & 2.65 & 0.75 & 0.05 & -0.40 \\
\hline 9. I am not confident about being pregnant. & $1-4$ & 3.51 & 0.65 & -1.24 & 1.54 \\
\hline 10. I am excited about childbirth. & $1-4$ & 3.02 & 0.72 & -0.13 & -0.75 \\
\hline 11. I feel affection for my unborn baby. & $2-4$ & 3.90 & 0.32 & -3.18 & 10.0 \\
\hline 12. I imagine how my pregnancy will be. & $2-4$ & 3.27 & 0.65 & -0.35 & -0.73 \\
\hline $\begin{array}{l}\text { 13. When I don't know what to do, I can probably research and solve } \\
\text { the problem by myself. }\end{array}$ & $1-4$ & 3.06 & 0.61 & -0.19 & 0.32 \\
\hline 14. I would like to enjoy my pregnancy. & $1-4$ & 3.64 & 0.56 & -1.74 & 4.26 \\
\hline 15. I can probably deal with what I am worried about. & $2-4$ & 3.24 & 0.48 & 0.54 & -0.21 \\
\hline 16. I can live with a positive attitude. & $1-4$ & 3.38 & 0.57 & -0.42 & 0.51 \\
\hline 17. I imagine how my delivery will be. & $1-4$ & 2.96 & 0.67 & -0.21 & -0.04 \\
\hline 18. My family and friends acknowledge my way. & $2-4$ & 3.33 & 0.52 & 0.28 & -1.00 \\
\hline 19. I think my strength for delivery is weaker than other people's. & $1-4$ & 3.29 & 0.72 & -0.89 & 0.80 \\
\hline 20. I am looking forward to life after childbirth. & $1-4$ & 3.57 & 0.60 & -1.24 & 1.42 \\
\hline $\begin{array}{l}\text { 21. I can always obtain information with which to consider the } \\
\text { birth plan and facilities for childbirth. }\end{array}$ & $2-4$ & 3.20 & 0.60 & -0.09 & -0.38 \\
\hline $\begin{array}{l}\text { 22. I have confidence about managing the pregnancy and that I can some- } \\
\text { how make do. }\end{array}$ & $2-4$ & 3.32 & 0.51 & 0.35 & -0.91 \\
\hline 23. I can probably determine when to see the doctor. & $2-4$ & 3.37 & 0.51 & 0.25 & -1.29 \\
\hline $\begin{array}{l}\text { 24. I can consult with others and ask for help in order to achieve my } \\
\text { goals. }\end{array}$ & $2-4$ & 3.40 & 0.52 & 0.13 & -1.37 \\
\hline 25. I feel that it is a reality that I will be a mother. & $2-4$ & 3.66 & 0.53 & -1.29 & 0.69 \\
\hline $\begin{array}{l}\text { 26. My family and friends understand my current situation by saying } \\
\text { "You can be as you are," and provide support . }\end{array}$ & $2-4$ & 3.42 & 0.56 & -0.28 & -0.84 \\
\hline 27. I am satisfied with my life. & $1-4$ & 3.60 & 0.54 & -1.13 & 1.68 \\
\hline
\end{tabular}


In order to investigate the internal consistency of the scale and based on the dimension organization proposed by Kameda and Shimada (2008), we analyzed the item-total correlations, Cronbach's alpha if item deleted and Cronbach's alpha for each dimension (Table 2). The EEG showed a Cronbach's alpha coefficient of .88 , similarly to the original study. We found acceptable internal consistency coefficients in all dimensions, except for the subscale Joy of an Addition to the Family, which, as in the original study, had a lower internal consistency value. Given that the value found was below.60, we decided to remove this dimension. These results are partly related to the behavior of items "I feel affection for my unborn baby" and "I would like to enjoy my pregnancy", as previously discussed. In the dimension Self-efficacy, the deletion of item 13 results in a slight gain in the value of internal consistency, thus we decided to remove it.

Table 2

Item-total correlations, Cronbach's alfa if item deleted and Cronbach's alfa for each dimension

\begin{tabular}{|c|c|c|c|}
\hline Dimensions/items & $\begin{array}{l}\text { Item-total } \\
\text { correlation }\end{array}$ & $\begin{array}{c}\text { Cronbach's } \\
\text { alfa if item } \\
\text { deleted }\end{array}$ & $\begin{array}{l}\text { Cronbach's } \\
\text { alpha }\end{array}$ \\
\hline Self-efficacy & & & .68 \\
\hline 1. I can obtain information I need from medical professionals. & .35 & .65 & \\
\hline 4. I can probably take care of what I need to do during the pregnancy. & .40 & .64 & \\
\hline $\begin{array}{l}\text { 13. When I don't know what to do, I can probably research and solve the } \\
\text { problem by myself. }\end{array}$ & .25 & .69 & \\
\hline 15. I can probably deal with what I am worried about. & .50 & .61 & \\
\hline $\begin{array}{l}\text { 21. I can always obtain information with which to consider the } \\
\text { birth plan and facilities for childbirth. }\end{array}$ & .49 & .60 & \\
\hline 23. I can probably determine when to see the doctor. & .48 & .61 & \\
\hline Future Image & & & .69 \\
\hline 2. I cannot imagine myself raising children. & .34 & .68 & \\
\hline 6. I cannot imagine an increase of my family. & .31 & .69 & \\
\hline 8. I have my ideal image of childbirth. & .52 & .61 & \\
\hline 12. I imagine how my pregnancy will be. & .47 & .63 & \\
\hline 17. I imagine how my delivery will be. & .44 & .64 & \\
\hline 25. I feel that it is a reality that I will be a mother. & .47 & .64 & \\
\hline Self-esteem & & & .74 \\
\hline 5 Even when I feel anxiety, I can shift certain emotional gears & .47 & .71 & \\
\hline 7. I probably can deliver like other people. & .50 & .70 & \\
\hline 9. I am not confident about being pregnant & .43 & .72 & \\
\hline 16. I can live with a positive attitude. & .57 & .69 & \\
\hline 19. I think my strength for delivery is weaker than other people's. & .49 & .71 & \\
\hline $\begin{array}{l}\text { 22. I have confidence about managing the pregnancy and that I can somehow make } \\
\text { do. }\end{array}$ & .40 & .73 & \\
\hline 27. I am satisfied with my life. & .38 & .73 & \\
\hline Support and Assurance from others & & & .72 \\
\hline 3. I can ask for help when I need to. & .42 & .71 & \\
\hline 18. My family and friends acknowledge my way. & .54 & .64 & \\
\hline 24. I can consult with others and ask for help in order to achieve my goals. & .54 & .64 & \\
\hline $\begin{array}{l}\text { 26. My family and friends understand my current situation by saying "You can } \\
\text { be as you are," and provide support. }\end{array}$ & .54 & .64 & \\
\hline Joy & & & .40 \\
\hline 10. I am excited about childbirth. & .23 & .34 & \\
\hline
\end{tabular}


Validity was first analyzed using an exploratory factor analysis. Kaiser-Meyer-Olkin (KMO) was .815 and the Bartlett's test of sphericity was $X^{2}(351)=1474.82 ; p<$ .001 , thus confirming that we could proceed with the analysis. We used Promax oblique rotation, following the procedures used by Kameda and Shimada (2008). We considered 30 to be the minimum saturation required for the association of an item to a factor. Eight components were extracted, explaining 59.02\% of the total variance. Since it did not correspond to the number of factors of the original study, we forced the factor analysis to five factors (as did the authors of the original version), which then explained $50.76 \%$ of the total variance. The solution found was not superposable with the factor solution of Kameda and Shimada (2008), although more than 50\% of the 27 scale items had loaded in the same dimensions of the original scale. For this reason, we moved on to the confirmatory factor analysis using AMOS (version 22, SPSS-IBM). We followed the indices and values described by Marôco (2010) to assess the goodnessof-fit of the model (CFI, TLI and RMSEA). The initial model showed a poor goodness-of-fit $\left(\mathrm{X}^{2} / \mathrm{df}=2.035\right.$; CFI $=.737$; PCFI $=.659$; RMSEA $=.079$ ). After removing outliers and deleting items with low factor loadings (items 4, 12, 15, 17, 22, 27), it was possible to obtain a good goodness-of-fit which supports the factorial validity of this instrument $\left(\mathrm{X}^{2} / \mathrm{df}=1.533\right.$; $\mathrm{CFI}=.913$; PCFI $=.746$; RMSEA $=.057$ ). Figure 1 shows the values of standardized factor loadings and the individual reliability of each item in the final model.

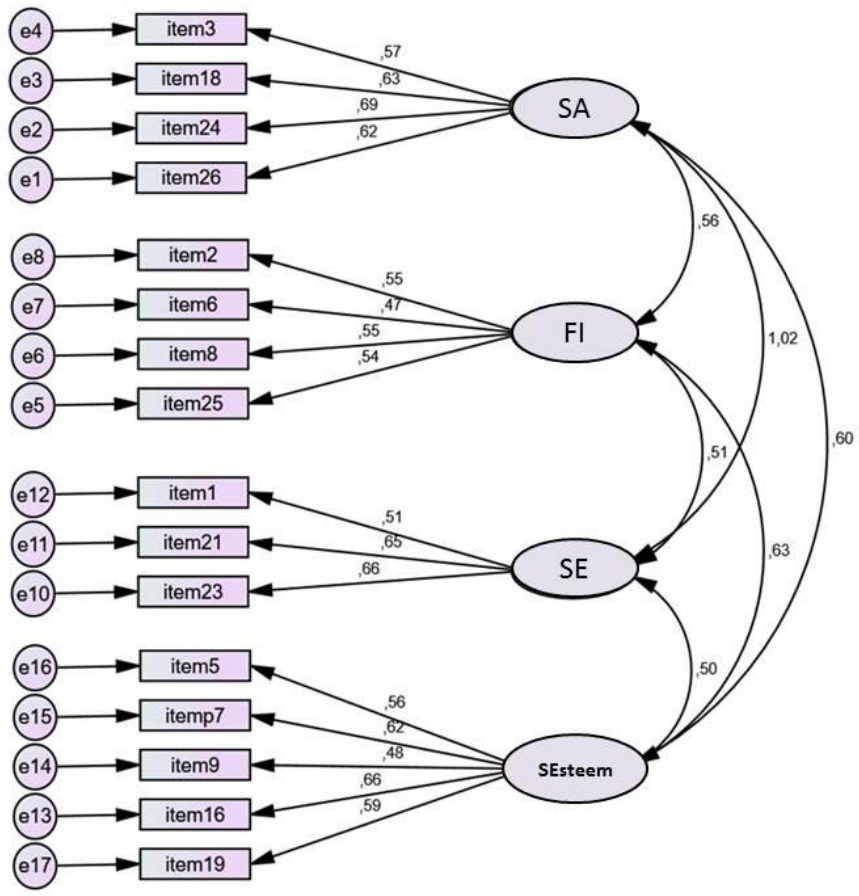

Figure1. Model resulting from the confirmatory factor analysis and standardized factor loadings.

Caption: SA - Support and Assurance from Others; FI- Future Image; SE- Self-Efficacy;

SEsteem- Self-Esteem

The analysis of the correlation matrix of the of significant correlation between the different EEG dimensions reformulated based on the results of the dimensions and the total scale. confirmatory factor analysis (Table 3) showed a matrix 
We reanalyzed the internal consistency of the scale restructured after the confirmatory factor analysis, and found the following Cronbach's alpha coefficients:

Table 3
.72 in Support and Assurance; 60 in Future Image; .56 in Self-efficacy; and .72 in Self-esteem.

Correlation matrix of the dimensions of the EEG

\begin{tabular}{|c|c|c|c|c|}
\hline & Self-efficacy & Self-esteem & Future Image & Support/Assurance \\
\hline Self-esteem & $.33 * *$ & & & \\
\hline Future Image & $.32 * *$ & $.49 * *$ & & \\
\hline Support and Assurance & $.70 * *$ & $.40 * *$ & $.37 * *$ & \\
\hline Total EEG & $.72 * *$ & $.78 * *$ & $.72 * *$ & $.79 * *$ \\
\hline
\end{tabular}

** Significant correlation set at 0.01 .

Through the correlation between the single-item scale on health perception and the EEG, we found that pregnant women with better health perception are those with higher levels of empowerment $(r=$ $.29, p=.0001$ ). In the analysis by dimension, we only found statistically significant correlations in Selfesteem $(r=.39, p=.0001)$ and Future Image $(r=$ $.16 ; p=.04)$.

The analysis of the correlation between the EEG and the Empowerment Scale, translated into Portuguese by Almeida and Pais-Ribeiro (2011), showed a moderate correlation between both scales $(r=.63, p$ $=.0001)$, thus confirming criterion validity.

\section{Discussion}

The framework of the concept of empowerment developed in this study is consistent with the definitions presented in the literature review (Gibson, 1991; Gibson, 1995; Hermansson \& Martensson, 2011; Rodwell, 1996; Rogers et al., 1997).

The Escala de Empowerment da Grávida proved to be easy to understand and apply, from the point of view of its use.

The attempt to perform an exploratory factor analysis to confirm the proposal of Kameda and Shimada (2008) was unsuccessful. Santos (2012) and Silva (2014), in their master's theses on the psychometric properties of this scale, found no factor solution superposable with the original version. Although Santos (2012) put forward a five-dimension proposal, the item allocation did not coincide with the original version. Silva (2014) also found no factor structure similar to the Japanese version, and decided to follow the authors' recommendations concerning its structure.
The solution found by the confirmatory factor analysis led to the elimination of a significant number of items, including one dimension. However, and according to some authors, each factor must ideally have between three and four items. These more economical and shorter versions bring about more advantages and applicability in clinical practice (Hair, Black, Babin, \& Anderson, 2010). The four-dimension model for empowerment of pregnant women emphasizes relevant areas of individual empowerment and decision-making, such as perceived control and competence, self-esteem, self-confidence, control over the future, positive identity, and ability to seek support. These aspects are important in the process of adaptation to pregnancy and transition to motherhood.

The results showed an expected association between the pregnant women's health perception and their levels of empowerment, thus contributing to ensure the convergent validity of the EEG.

The moderate association found between the EEG and other empowerment scale allowed us to conclude on criterion validity.

Internal consistency values are acceptable, despite the small number of items per dimension (three or four). Thus, the instrument meets reliability criteria, showing that each dimension assesses different but complementary parts of the same concept. We recommend that future studies analyze its behavior in terms of temporal stability. In other words, the application of the test at different times and in different locations should have no impact on the results.

Although this new structure ensures reliability and validity characteristics, we acknowledge the need for further studies that could add more consistency to the solution presented here. 


\section{Conclusion}

Based on these results, the EEG is a reliable and valid tool which was adapted to study the level of empowerment of Portuguese pregnant women. However, further studies are needed to reexamine the psychometric properties of the scale.

The EEG allows identifying the level of empowerment of pregnant women and its use in health care settings promotes the nursing process, specifically the diagnostic activity and the definition of the pregnant woman's profile, so as to establish which intervention strategies will be used for the promotion of empowerment in prenatal care and in childbirth and parenthood preparation classes.

The identification of the pregnant woman's level of empowerment enables the differential diagnosis of the characteristics of pregnant women and their needs, thus providing the opportunity for the provision of care based on the meaning attached by each pregnant women to pregnancy, childbirth and motherhood.

It should also be noted that the key challenge for nurses is moving toward person-centered care practices, in which the nurse, together with the pregnant woman, assesses her needs and, simultaneously, promotes informed decision-making, autonomy and self-esteem, which are essential components of the empowerment process, without forgetting the crucial role of the support network of family and friends.

\section{References}

Almeida, M. C., \& Pais-Ribeiro, J. L. (2011). Empowerment em adultos na comunidade: Estudo preliminar de adaptação de uma escala para a população portuguesa. In Escola Superior de Enfermagem do Porto, Núcleo de Investigação em Saúde e Qualidade de Vida (Ed.), Saúde e qualidade de vida: Uma meta a atingir (pp. 76-80). Retrieved from http://portal.esenf.pt/www/pk_menus_ficheiros.ver_ ficheiro?fich =F721889083/E-book_final.pdf

Beaton, D. E., Bombardier, C., Guillemin, F., \& Ferraz, M. B. (2000). Guidelines for the process of cross-cultural adaptation of self-report measures. Spine, 25(24), 3186-3191. doi: 10.1097/00007632-200012150-00014

Carvalho, G. C. (2005). Sentido de coerência, ligação materno fetal e estilo de vida da mulher durante a gravidez (Dissertação de mestrado, Universidade Nova de Lisboa, Escola Nacional de Saúde Pública). Retrieved from http:// www.ensp.unl.pt/saboga/soc/pulic/05_sco_vinculo_ materno_fetal_gravidez.pdf
Conselho Internacional de Enfermeiros. (2002). Classificação internacional para a prática de enfermagem: CIPE/ICNP: Versão Beta 2. Lisboa, Portugal: Associação Portuguesa de Enfermeiros.

Gibson, C. H. (1991). A concept analysis of empowerment. Journal of Advanced Nursing, 16(3), 354-361. doi: 10.1111/ j.1365-2648.1991.tb01660.x

Gibson, C. H. (1995). The process of empowerment in mothers of chronically ill children. Journal of Advanced Nursing, 21(6), 1201-1210. doi: 10.1046/j.1365-2648.1995.21061201.x

Hair, J., Black, W., Babin, B., \& Anderson, R. (2010). Multivariate data analysis $\left(7^{\text {th }} \mathrm{ed}\right.$.). New Jersey, USA: Pearson Educational.

Hermansson, E., \& Martensson, L. (2011). Empowerment in the midwifery context: A concept analysis. Midwifery, 27(6), 811816. doi: 10.1016/j.midw.2010.08.005

Kameda, Y., \& Shimada, K. (2008). Development of an empowerment scale for pregnant women. Journal of the Tsuruma Health Science Society Kanazawa University, 32(1), 39-48. Retrieved from http://dspace.lib.kanazawa-u. ac.jp/dspace/bitstream/2297/10997/1/AA11599711-32-1kameda.pdf

Levinson, W., Kao, A., Kuby, A., \& Thisted, R. A. (2005). Not all patients want to participate in decision making: A national study of public preferences. Journal of General Internal Medicine, 20(6), 531-535. doi: 10.1111/j.15251497.2005.04101.x

Marôco, J. (2010). Análise de equações estruturais: Fundamentos teóricos, software \& aplicações. Pêro Pinheiro, Portugal: Report Number.

Organização Mundial de Saúde. (2001). Relatório sobre a saúde no mundo: Saúde mental: Nova conceção, nova esperança. Genebra, Suiça: Autor.

Ribeiro, J. L. (2005). O importante é a saúde: Estudo de adaptação de uma técnica de avaliação do estado de saúde: SF-36. Porto, Portugal: Merck Sharp e Donhme.

Rodwell, C. M. (1996). An analysis of the concept of empowerment. Journal of Advanced Nursing, 23(2), 305-313. doi: 10.1111/ j.1365-2648.1996.tb02672.x

Rogers, S. E., Chamberlin, J., Ellison, M. L., \& Crean, T. (1997). A consumer-constructed scale to measure empowerment among users of mental health services. Psychiatric Services, 48(8), 1042-1047. Retrieved from https://cpr.bu.edu/wpcontent/uploads/2011/11/rogers1997c.pdf

Santos, I. M. (2012). Empoderamento da grávida durante a vigilância da gravidez (Dissertação de mestrado). Instituto Politécnico de Viseu, Portugal.

Silva, D. N. (2014). Empowerment da grávida: Fatores de capacitação para a maternidade (Dissertação de mestrado). Instituto Politécnico de Viseu, Portugal.

Zimmerman, M., \& Perkins, D. (1995). Empowerment theory: Research and application. American Journal of Community Pbsycology, 23(5), 569-579. doi: 10.1007/BF02506982 

